\title{
Erratum
}

Cold Spring Harb Protoc 2010; doi: 10.1101/pdb.prot4806

\section{Erratum: Staining for Acetylcholinesterase in Brain Sections}

\author{
Carol Ann Paul, Barbara Beltz, and Joanne Berger-Sweeney
}

When this article was first published, the recipe entitled "Sodium acetate buffer ( $0.2 \mathrm{M}, \mathrm{pH} \mathrm{5.0)}$ " (which is used in the acetylcholinesterase stain) listed "sodium acetate" as one of the reagents to be used. However, this reagent should have been "sodium acetate trihydrate," which will produce a final concentration of $0.2 \mathrm{M}$ sodium acetate in the solution. A corrected version of the recipe is below. In addition, the HTML version of the recipe (doi: 10.1101/pdb.rec11203) has been amended.

Sodium Acetate Buffer (0.2 M, pH 5.0)

Reagent

Quantity (for 2 L)

Sodium acetate trihydrate

$54.43 \mathrm{~g}$

Glacial acetic acid

$12 \mathrm{~mL}$

$\mathrm{H}_{2} \mathrm{O}$

$1988 \mathrm{~mL}$

Combine the reagents and adjust the $\mathrm{pH}$ to 5.0 with $10 \mathrm{~N} \mathrm{NaOH}$. 


\section{Erratum: Staining for Acetylcholinesterase in Brain Sections}

Carol Ann Paul, Barbara Beltz and Joanne Berger-Sweeney

Cold Spring Harb Protoc; doi: 10.1101/pdb.err101634

\begin{aligned} & \hline $\begin{array}{r}\text { Email Alerting } \\ \text { Service }\end{array}$ Receive free email alerts when new articles cite this article - click here. \\ & \hline $\begin{array}{c}\text { Subject } \\ \text { Categories }\end{array}$ Browse articles on similar topics from Cold Spring Harbor Protocols. \\ & \hline\end{aligned}

